\title{
Effect of Nursing Intervention on Weight Loss of Obese Older Adults
}

\author{
Doaa Abd Elhameed Abd Elmawla, Lecturer \\ Gerontological Nursing, Faculty of Nursing, Mansoura University
}

\author{
Aziza Mahmoud Boughdady, Lecturer \\ Gerontological Nursing, Faculty of Nursing, Mansoura University \\ Eman Hassan Mounir Radwan, Lecturer \\ Gerontological Nursing, Faculty of Nursing, Mansoura University
}

\begin{abstract}
Obesity and a sedentary lifestyle are an increasing worldwide health problem. Obesity is recognized as a major health threat throughout the life-span affecting all ages particularly older adults. Overweight and obesity are commonly associated with comorbidities that significantly deteriorate quality of life and expectancy. Behavioral interventions are the initial approach recommended for the prevention, as well as treatment of obesity. Objective: Determine effect of nursing intervention on weight loss of obese older adults. Setting: The study was carried out in geriatric outpatient clinic at Specialized Medical Hospital, Mansoura University, Egypt. Subjects: The study included 66 obese older adults of both sex, aged 60 year and more, able to communicate, accept to participate in the study, and available at the selected setting during the period of data collection. Tools: Data was collected using four tools, Demographic and clinical data structured interview sheet of obese older adults, Obesity knowledge structured interview sheet, Self reported health behaviors related to weight loss structured interview sheet and Physical activity scale for the elderly (PASE). Results: Results of the study indicate, $78.8 \%$ of the study subjects were females. There was significant decrease in mean body mass index (39.05 $\pm 3.19 \mathrm{vs}$. $37.54 \pm 3.48, p \leq 0.001)$ with a mean weight of $(107.36 \pm 4.76 \mathrm{vs} .103 .31 \pm 6.12 \mathrm{~kg}, p \leq 0.001)$, indicating mean weight loss of $4.05 \mathrm{~kg}$. Significant improvements were observed regarding obesity knowledge, adoption of health behaviors and physical function particularly among elderly women. a significant improvement in self perception of body weight and perceived obesity risks among the studied elders, $p \leq 0.001$. Conclusion: This study reflects that weight loss nursing intervention based on healthy hypo-caloric diet with increased physical activity and behavioral change had marked reduce in body weight with improvement in physical function. Recommendations: Obesity prevention efforts should be applied in primary care settings, where health care providers have longitudinal relationship with geriatric patients and can provide a brief, motivational interviewing to engage them in behavioral change to maintain their weight.
\end{abstract}

Keywords: Obesity; Weight loss; Older adults; Physical function.

or excessive fat accumulation that may impair health. Body mass index (BMI) has

\section{Introduction}

Obesity is a major health threat throughout the lifespan affecting all ages particularly older adults in both developed and developing countries ${ }^{(1)}$. Obesity in elderly is a complex and multifactorial disease; it is a consequence of genetic, environmental, lifestyle and emotional factors $^{(2)}$. In general, this condition is due to imbalance between energy intake and consumption which promotes excessive fat deposition that is accentuated by ageing ${ }^{(3)}$.

Obesity is defined by the World Health Organization (2018) as an abnormal been widely used and accepted as a method of classifying overweight, obesity, and medical risk by weight status. An individual with a body mass index of 30 or more is generally considered obese. BMI is calculated as body weight (in $\mathrm{kg}$ ) divided by the square of height (in meter) ${ }^{(4)}$.

The prevalence of obesity in older adults continues to rise over time bringing massive and rapidly increasing pressure on societies as well as the health care systems $^{(5)}$. Worldwide obesity has nearly tripled since 1975 where $39 \%$ of adults were overweight, and $13 \%$ were obese ${ }^{(6,7)}$. 
In USA recent estimates from the national health and nutrition examination surveys demonstrated that older adults over the age of 60 have obesity rates exceeding $37.5 \%$ in males and $39.4 \%$ in females ${ }^{(8)}$, while in Egypt $33.3 \%$ of people aged 60 years or older meet the obesity definition (BMI $\geq$ $30)^{(9)}$. Also, it is considered a serious leading risk factor for deaths all over the world as overweight and obesity are linked to more deaths worldwide than underweight $^{(7)}$.

Alongside with the ageing process, some physiological changes in body composition may predispose to obesity such as a reduction in lean mass (including muscle and bone mass) and consequent increase in fat accumulation, especially in abdominal area. The decrease in muscle mass is also responsible for a slower metabolism, which contributes to the appearance of excess body weight ${ }^{(10)}$. Also, hormonal changes associated with aging may cause accumulation of fat as decrease in growth hormone secretions, reduced responsiveness to thyroid hormone, decline in serum testosterone, and resistance to leptin ${ }^{(11)}$. Furthermore, elders have probability to be more sedentary, which leads to a low total daily energy expenditure leading to further weight gain 12).

Despite the prevalence of obesity is higher in females older adults than males, obesity has negative consequences on health status of both men and women ${ }^{(13)}$. Obesity influences the older adults' level of wellness as it is associated with comorbidities that significantly deteriorate quality of life and expectancy ${ }^{(14)}$. It is connected with increased morbidity, and greater risk for developing chronic illnesses such as hypertension, diabetes mellitus, cardiovascular diseases, stroke, and osteoarthritis $^{(15)}$. Additionally, obesity can exacerbate age-related decline in physical function, particularly mobility which is markedly diminished and poses a threat to independence in overweight and obese elders $^{(13,16,17)}$. The deterioration of functional status severely impacts the quality of life for obese older adults, increasing risk of falls and enhancing the likelihood of institutionalization ${ }^{(5,18)}$.

In general, obesity causes a list of complications which affect all body system, and even modest intentional weight loss (5$10 \%$ ) brings multiple benefits ${ }^{(3,19)}$. However, these benefits cannot be assumed to apply in the elderly without hazards because of weight reduction inevitably incorporates loss of muscle and bone mass in addition to age dependent gradual decline in lean body mass ${ }^{(20)}$. Thus, weight loss intervention should be cautions in older adults to limit lean body mass loss and nutritional deficiencies. For the treatment of obese elders aged 65 , a diet that includes moderate calorie restriction by $500-750$ kcal / day ${ }^{(21)}$ or a $15-30 \%$ decrease in calorie intake from habitual intake ${ }^{(22)}$ and a higher intake of protein is recommended ${ }^{(23)}$. In addition, the guidelines asserted that 150 min / week of moderate intensity exercise as walking should be performed by older adults to manage their weight ${ }^{(22,24)}$. Physical exercise combined with the diet is essential to lose weight, improve functional status, maintain muscle mass and bone tissue ${ }^{(21,25)}$.

Gerontological nurses have a responsibility in the prevention and management of obesity by identifying obese older adults and assisting them through health promotion intervention to adopt health behaviors to lose weight and decrease the negative consequences of obesity $^{(26)}$. One of the most common approaches to help older adults to lose weight is a combination of eating healthy low calorie diet, increased physical activity, and changes in behavior patterns. These measures if adopted, will result in moderate weight loss with an improvement of obesity related comorbidities, physical dysfunction, and quality of life and reduces associated medical complications ${ }^{(27)}$.

\section{Aim of the Study}

Determine effect of nursing intervention on weight loss of obese older adults. 
The aim was achieved through:

Evaluate effect of implementing weight loss nursing intervention on obesity knowledge, body weight perception, perceived obesity risks and heath behaviors of obese older adults.

Evaluate effect of implementing weight loss nursing intervention on body weight, BMI and physical function of obese older adults.

\section{Research Hypothesis}

Obese older adults who are engaged in the weight loss nursing intervention will report high level of knowledge about obesity, adoption of health behaviors related weight loss, and improvement in $\mathrm{BMI}$, and physical function

\section{Materials and Method}

\section{Materials}

Design: Quasi-experimental, pre and post intervention research design was used in this study.

Setting: The study was carried out in geriatric outpatient clinic at Specialized Medical Hospital, Mansoura University, Egypt.

Subjects: The study included 66 obese older adults $(\mathrm{BMI} \geq 30)$ of both sex, aged 60 year and more, able to communicate, accept to participate in the study, and available at the selected setting during the period of data collection. The sample size was estimated through DDS research using average values of BMI change in previous study ${ }^{(28)}$ (31.04 \pm 6.38 vs. $30.14 \pm 6.15$ ) with a statistical power $80 \%$ and alpha error level 5\%. The estimated sample size was 63 and added $5 \%$ because of defaulter, so the sample size was 66 obese older adults. Elders with unstable cardiac disease, sever physical disability that precluded walking, with a history of debilitating diseases, history of diabetes mellitus and use of corticosteroids or hormonal therapy were excluded from the study.
Tools: Four tools were used in the study to collect the necessary data:

Tool I: Demographic and clinical data structured interview sheet of obese older adults

This tool was developed by the researchers after review of the relevant literature to assess the demographic characteristics and clinical data of the study subjects. It included 4 parts:

- Demographic characteristics such as age, sex, marital status, level of education, residence, living condition, and income.

- Clinical data as history of obesity and its associated problems (as mobility problems, musculoskeletal pain, sleep problems, respiratory problems, and fatigue), weight loss efforts if adopted, and presence of comorbidities.

- Perception about obesity including statements regarding body weight perception and perceived obesity risks for developing chronic diseases compared with other elders with normal body weight.

- Physiological measures as BMI, waist circumference, and blood pressure for hypertensive cases.

\section{Tool II: Obesity Knowledge Structured Interview Sheet}

Researchers developed this tool based on review of literature. This tool was used to assess baseline knowledge of obese older adults about obesity. It included a set of questions related nature of obesity (14 questions) including definition, BMI formula, risk factors, manifestations, and complications. Health behaviors regarding weight loss (8 questions) namely healthy diet, physical activity, and risk behaviors. Each question had a group of suggested responses, each of the correct response scored one, while no or wrong answer scored zero. The score obtained for each question was summed up to get the total 
score for patient's knowledge. The total score was computed out of 100.

\section{Tool III: Self Reported Health Behaviors Related to Weight Loss Structured Interview Sheet}

This tool was developed by the researchers after review of the relevant literature to evaluate participants' health behaviors related weight loss through five dimensions; dietary habits, physical activity, follow-up, sleep pattern, and stress management. Each dimension contains a number of questions; the total number of questions is 38. It was developed in a 4point ordinal response format to measure frequency of self-reported health behavior. Each item had four possible responses: 1 (never), 2 (sometimes), 3 (often), and 4 (always). A score for overall health behaviors was obtained by calculating a mean of the participant's responses to all 38 items; five dimensions scores were obtained similarly by calculating a mean of the responses to each dimension items. So, each of the five dimension score could range from 1 to 4 , and the total score ranges from 5 to 20 .

\section{Tool IV: Physical Activity Scale for the} Elderly (PASE)

PASE was developed by Washburn et al., $1993^{(29)}$. It is an easily administered and scored instrument that measures the level of physical activity in individuals aged 65 years and older. The PASE is evaluating the physical activity through 12 questions in three life domains: recreational, household and work-related activity over 7 days. Subjects rate their weekly frequency (responses range from $0=$ never means no activity to $3=$ often means 5-7 days/week), and daily duration (responses range from $1=$ less than 1 hour $/$ day to $4=$ greater than 4 hours/day) for the following recreational activities; walking outside home, light, moderate and strenuous activities and muscle strengthening. While household activities (light and heavy housework, home repairs, lawn work/yard care, outdoor gardening and caring for others) were answered yes or no. Finally, working for pay or as a volunteer was assessed by recording the working hours per week. For each activity, a score was obtained by multiplying an activity frequency value by a task-specific weight provided by the scoring manual. The PASE total score, which represents the overall physical activity level, is the sum of all activities together, and ranges between 0 and 400 or more. A higher PASE score indicating a person is more physically active.

\section{Method}

- An official permission was issued from the responsible authorities of Faculty of Nursing, Mansoura University.

- Permission to conduct the study was obtained from the head of geriatric outpatient clinic - specialized medical hospital - Mansoura University after being informed about the purpose of the study and the time of data collection.

- The study tool I (Demographic and clinical data structured interview sheet), tool II (Obesity knowledge structured interview sheet), and tool III (Self reported health behaviors related to weight loss structured interview sheet) were developed by the researchers after reviewing the relevant literatures.

- Tool IV (Physical activity scale for the elderly) was translated into Arabic by the researchers. Back translation was used by an expert in English language from Faculty of Education, English Department, Mansoura University to ensure the validity of tool translation.

- The study tools were tested for content validity by five experts in the related fields of the study and the required modifications were done accordingly.

- Reliability of tool IV was tested by determining the extent to which PASE scores were stable over 
repeated administrations. It was assured by means of $r$ coefficient $(\mathrm{r}=0.84)$.

- Education materials were developed by the researchers based on current evidence $^{(22,30,31,32)}$. It was written in simple Arabic language and illustrated by photos to help the participants understanding the content. Booklet was printed in colored large font.

- A pilot study was conducted on 10 obese older adults who were selected from the study setting before starting the data collection to ascertain the clarity and applicability of the study tools and the necessary modifications were done. These patients were not included in the study sample.

- Based on the schedule of the geriatric outpatient clinic at specialized medical hospital, the researchers visited the clinic one day/week (Wednesday).

- The researchers started by introducing themselves to the study participants and giving them a brief idea about the aim of the study.

- Older adults who fulfill the inclusion criteria were enrolled in 12-week weight loss nursing intervention. They were interviewed individually by the researchers in the waiting area in the outpatient clinics to collect the baseline data using the study tools.

- The researchers weighed the study subjects' weight using digital bathroom scale after adjusted to zero and measured their height using a measuring tape. Then, the BMI was calculated as body weight (in $\mathrm{kg}$ ) divided by the square of height (in meter).

- The waist circumference was measured by asking the participant to relax and not to contract any abdominal muscles. Align the tape measure at the level of the belly button, and circle the whole way around the body and back to the starting point.

- Blood pressure was measured for hypertensive cases using manual mercury sphygmomanometer.

- The researchers implemented the intervention program individually. The basic of the intervention was a behavioral lifestyle modification that provided as health recommendations for weight loss. Participants attended two sessions; one session a week as follow:

- The first session included information about the nature of obesity, risk factors, and consequences.

- The second session, participants were taught various behavioral strategies to modify their dietary habits and improve physical activity. They were instructed to eat a low calorie balanced diet rich with proteins, fruits, and vegetables $^{(22)}$. Also, they were given an exercise plan to gradually increase their physical activity; walking 90-150 minute week, as $30 \mathrm{~min} /$ day for three or five nonconsecutive days / week was chosen based on the recent evidence ${ }^{(33)}$. Finally, the intervention involved instructions about modifying bad behaviors as avoid sitting most of the time, do not skip breakfast and avoid eating in the night time, and avoid snaking between meals.

- Immediately after the sessions, the study participants were interviewed to evaluate the effectiveness of the sessions using the study tool II (Obesity knowledge structured interview sheet).

- During the sessions, the researchers used power point presentation using lap top, and used simple, brief, clear words. At the end of each session, a 
brief summary was given by the researchers, emphasizing on the most important points.

- The participants' adherence to the intervention was assessed using weekly self reported telephone calls. Also, caregivers (if present) were asked to guide the elders to comply with the instruction to achieve better outcomes. Instructions booklet was given to each participant.

- The researchers evaluate the effectiveness of the weight loss intervention after 12-week from the implementation using the study tools (part c and d tool I, tool II, tool III, and tool IV).

- The study was conducted over a period of six months beginning from the first of July 2018 till the end of December 2018.

\section{Ethical considerations:}

Ethical approval was obtained from Mansoura University Faculty of Nursing Ethic Committee. Verbal consent was obtained from elderly persons after explanation of the nature of the study and its potential benefits. The elders were informed that their participation is voluntary and they can withdraw from the study at any time. Confidentiality and anonymity of the collected data were assured.

\section{Statistical Analysis}

Data was analyzed using SPSS (Statistical Package for Social Sciences) version 16. Qualitative variables were presented as number and percent. Quantitative variables were tested for normality distribution by Shapiro test. Normally distributed variables were presented as mean and standard deviation and paired t-test was used for pre-post comparison, while Wilcoxon sign test was used for paired comparison in non parametric variables. Independent t-test was used to compare two groups, and one way ANOVA test was used for more than two groups' comparison. Pearson's correlation coefficient was used to quantify association between different variables. $\mathrm{P} \leq 0.05$ was considered statistically significant.

\section{Results}

This study included 66 obese older adults. The study participants' age ranged from 60 to 74 years with a mean age of 65.51 44.46. Females constituted $78.8 \%$, and illiteracy was prevailing among $39.4 \%$ of the studied subjects. Also, $89.4 \%$ presented with a history of chronic diseases; of those, $63.6 \%$ had hypertension, $56.06 \%$ had osteoarthritis, $19.69 \%$ had GIT problems, $18.2 \%$ had cardiac disease, and $13.63 \%$ had respiratory problems as bronchial asthma. Only $24.24 \%$ had positive family history of obesity, and $19.7 \%$ reported trying to lose weight.

Table (1) reports obesity knowledge of the studied elders pre, immediate and 12 week post intervention. There was a significant improvement in elders' knowledge in the immediate post intervention; however it decreased slightly 12 week after intervention. This pattern of improvement persists after stratification of studied elders according demographic characteristics, presence or absence of chronic diseases, and weight loss efforts $(\mathrm{p} \leq 0.001)$.

Table (2) illustrates health behaviors of the studied elders pre and 12 week postintervention. The overall mean score of health behaviors related to weight loss improved at 12 week post intervention. These improvement was statistically significant with $\mathrm{p} \leq 0.001$. This pattern of improvement persists after stratification of studied elders' according demographic characteristics.

Table (3) reveals outcome measures taken pre and 12 week post-intervention for the studied elders and its variation by gender. There was a significant decrease in mean of body weight $107.36 \pm 4.76$ vs. $103.31 \pm 6.12 \mathrm{~kg}, \mathrm{p} \leq 0.001$, with a mean weight loss of $4.05 \mathrm{~kg}$. This reflects an average reduction of $3.8 \%$ from initial body 
weight. Seventeen elders $(25.7 \%)$ achieved $5 \%$ weight loss, whereas 42 elders $(63.6 \%)$ achieved $1 \%$ to $5 \%$ weight loss. Two participants (3.1\%) gained weight from 1 to $2 \mathrm{~kg}$, and the rest $(7.6 \%)$ not achieve any weight loss. This variation affected by participants' gender, as females had significant decrease in body weight rather than males $(\mathrm{p}=.038)$. Also, all other measures decreased significantly at 12 week post intervention, but there was no difference by gender. As well as, study participants were more physically active at 12 week post intervention with gender difference $(\mathrm{p}=.041)$.

Figure (1) reveals that participants' age affected significantly the physical activity pre and post intervention $\mathrm{F}=33.184$ $(\mathrm{p} \leq 0.001) \quad$ and $\quad 155.95 \quad(\mathrm{p} \leq 0.001)$ respectively.

Table (4) represents the effect of weight loss nursing intervention on elders' self perception about their body weight and perceived obesity risks. A Wilcoxon singed ranks $\mathrm{Z}$ test revealed a significant difference between self perception of body weight and perceived obesity risks among the studied elders before and after the intervention $\mathrm{p} \leq 0.001$. Obese elders consistently rated their body weight smaller than their actual body weight, as only $12.1 \%$ perceived themselves as obese before the intervention and changed to $86.4 \%$ who perceived themselves as obese after the intervention. Concerning risks for developing chronic diseases as a consequence of obesity and compared to other, only $33.3 \%$ perceived themselves at risk and $57.5 \%$ perceived themselves at risk more than other elders. This percent increased to $87.9 \%$ and $96.9 \%$ respectively after the intervention.

Table (5) illustrates the relation between studied elders' perception about obesity risks and the study variables 12 week post-intervention. There was a statistical significant relation between perceived obesity risks and either total knowledge score or total health behaviors score $(\mathrm{p}=0.004,0.013$ respectively), as elders who perceived themselves at risk for developing chronic diseases more than other elders had higher knowledge score and adopting healthy behaviors than other elders. But there was no relation between perceived obesity risks and body mass index.

Table (6) represents positive correlation between total knowledge score and total health behaviors score. As, health behaviors was higher among participants who had high level of knowledge. Also, there was negative correlation between total knowledge score, total health behaviors score, and body mass index. This means that, participants who had higher score of knowledge and health behaviors had improvement (decreased) in body mass index. Moreover, physical activity was correlated positively with total knowledge and health behaviors, and negatively with BMI $(\mathrm{p} \leq 0.001)$.

\section{Discussion}

Today's, the obesity epidemic among older adults is expected to continue increasing unless public-health efforts address this age group ${ }^{(34)}$. Weight loss in older adults is considering a challenge than in younger adults where low muscle mass and consequent physical frailty, osteoporosis, comorbid disease and cultural differences may interfere with weight loss intervention $^{(27)}$. So, this study aimed to determine effect of nursing intervention on weight loss of obese older adults.

Effective management of obesity should consider patients' awareness of their condition as it will enable them to engage in healthy lifestyles. Nurses need to develop intervention to promote healthy aging among obese older adults through education and information giving about the risks of obesity and focusing on lifestyle modifications $^{(26)}$. Many studies reported that older adults are unaware of their weight status and heath consequences ${ }^{(35,36)}$. The present study findings revealed that total knowledge score improved significantly immediately after intervention, however it decreased slightly 12 week follow up (table 1). This is in accordance with Fatmah 
$(2013)^{(37)}$ in Indonesia and Nanda et al, $(2015)^{(38)}$ in USA, the first reported that obesity knowledge improved through training and post training intervention, and the second concluded that providing information about BMI and weight loss, not only assist patients to become better informed about their personal health and associated risk factors, but they also become more motivated to lose weight. Another study done in USA revealed that all participants reported greater awareness about obesity, sedentary behaviors, consequences of sitting, and ways to reduce sitting time ${ }^{(39)}$.

\section{Lifestyle modification is} recommended as the current challenge for weight loss in older adults. As care providers for older adults, continuing information providing helps them to adopt healthy lifestyle and manage their body weight. The primary goal to achieve sustained changes is through a combination of a reduced calorie healthy diet and increased physical activity ${ }^{(32,40)}$. In this respect, the present study showed significant improvement concerning total health behaviors score after the intervention implementation (table 2). These results are in agreement with a study carried out in USA by Villareal et al., $(2006)^{(41)}$ who study the effect of lifestyle intervention on metabolic coronary heart disease risk factors in obese older adults and concluded that most participants assigned to the intervention were compliant with the lifestyle intervention program. Another study in USA done by Nocera et al., $(2011)^{(42)}$ evidenced that lifestyle intervention involving modification of dietary and exercise patterns are effective in producing clinically significant improvement in obese older adults. In addition, these findings are consistent with de Roon et al., (2017) ${ }^{(43)}$ in Europe who reported a sustained weight loss after 16week from implementation of the weight loss program in overweight and obese post menopausal women with an inactive lifestyle.
A combination of diet induced weight loss, behavior modification, and increase level of physical activity may be suitable for obese older adults. The effectiveness of the intervention was determined by changes in physiological outcomes. As shown in our study findings that revealed improvement in all outcome measures including body weight, BMI, waist circumference, systolic and diastolic blood pressure. Additionally, women reported significant weight loss more than men with no differences in BMI (table 3). This finding may be attributed to the fact that women adopt healthy behaviors more than men or women interested in managing their weight rather than men and this difference may appears in BMI if the study was extended for a long period. These data are consistent with Anton et al., (2011) ${ }^{(44)}$ in USA, suggested that moderate caloric restriction plus moderate exercise can produce significant weight loss and improve physical function while maintaining muscle strength in obese older women. Additionally, these results are an extension of previous studies by Jensen et al., (2004) $)^{(45)}$, Villareal et al., (2006) $)^{(41)}$, and Ard et al., $(2018)^{(33)}$ in USA, which reported in their researches that weight loss intervention has considerable beneficial effects on body weight and other outcome measures in obese older adults. A qualitative study in England allows the participants to express their views and impressions about the intervention program and inform about the optimal body weight reduction methods to achieve better outcomes (Alrushud et al., 2018) ${ }^{(46)}$.

On the contrary, a study in USA (2017) investigated the effectiveness of adopting lifestyle intervention for adults with impaired mobility revealed modest improvements in waist circumference and blood pressure likewise were not statically significant, however demonstrated a significant mean weight loss and attributed this difference to the nature of disability of the participants ${ }^{(47)}$.

Older adults may be particularly susceptible to adverse effects of obesity on 
physical function and increased risk of functional decline because of the decrease in muscle mass and strength that occurs with aging ${ }^{(1)}$. Conversely, exercise and weight loss intervention have been shown to be effective in improving physical function of obese older adults ${ }^{(44,48)}$. The present study revealed that a reduction in body weight has an independent effect on physical function at 12-week following the intervention. It was hypothesized that reducing body weight or the load to move is more important for improving physical function particularly for older women who have greater adiposity. Moreover, the older women were more physically active than older men after implementation of the intervention; this can be justified by the fact that PASE instrument assessed various component of physical activity, including walking outside home as for shopping, caring for another person, and performing light or heavy house work activities. These types of physical activity are more likely to be performed by women. These data are consistent with previous researches in USA that reported the effectiveness of weight loss intervention in improving physical function and preventing future physical disability in obese older adults ${ }^{(21,44,49,50)}$. Additionally, a previous qualitative study in UK (2019) revealed acceptance of weight management as an important issue that has significant impact on physical and mental health ${ }^{(51)}$.

The present study revealed that physical activity was higher among elders aged less than 70 years compared with those aged more than 70 years before and after the intervention (figure 1). This result may be due to the effect of aging process and lack of energy that decrease the ability of older adults to engage in physical activity. The finding is in agreement with a study done in Japan by Takagi et al., $(2015)^{(52)}$ who stated that medium intensity of physical activity declines with age in older adults. On the other hand a study in America by Johannsen et al., (2008) ${ }^{(53)}$ reported that physical activity was similar between young and older adults, likely due to the sedentary nature of the society.

In light of high prevalence of overweight and obesity among older adults, nursing intervention should consider body weight perception to effectively motivate obese elders to lose weight ${ }^{(54,55)}$. In this respect, the present study revealed significant change in perceived body weight and obesity risks among the study participants, as obese elders consistently rated their body weight smaller than their actual body weight before the study and then perceived themselves as obese and risky for obesity consequences (table 4). This may attributed to lack of knowledge about obesity or BMI to evaluate their body weight and only depend on their body appearance. This is in agreement with a study conducted in Egypt (2017) which reported more than half of elders view their body weight as normal and accept it despite the higher percentages of either overweight or obese among them ${ }^{(56)}$. Similarly, a study conducted in Tanzania (2012) repoted the same findings ${ }^{(57)}$.

Furthermore, the present study reported that elders who perceived themselves at risk for developing chronic diseases had higher knowledge score and adopting healthy behaviors (table 5). Indicating that health perception may be a good motivation for acquiring knowledge about the problem and adopting healthy behaviors to overcome the problem. This is consistent with a study in Egypt (2016) which revealed a significant relation between perceived susceptibility and adopted preventive behaviors of $\mathrm{CHD}^{(58)}$. Other studies conducted in Korea supported the study findings and reported health literacy, health risk perception, and health concern were independently associated with health behaviors ${ }^{(59,60)}$. While Fenner $(2002)^{(61)}$ in USA suggests different results where health perception did not affect health promotion behaviors in older adults.

In this study, obesity awareness, healthy behaviors, body weight, and physical activity are interrelated variables. The study revealed a positive correlation 
between elders' knowledge, health behaviors, and physical activity. While, revealed a negative correlation between BMI and the other mentioned variables. This means that, elders having high level of knowledge are adopting healthy behaviors which lead to decrease in BMI and increase in physical function. This is in accordance with Al-Wehedy et al., (2014) ${ }^{(62)}$ in Egypt and Mills et al., (2016) ${ }^{(63)}$ in UK, the first found a strong positive correlation between knowledge and lifestyle patterns and the later stated that particular lifestyle habits show correlation with BMI measures in both males and females older adults.

The study results reported that there is a statistically significant difference between demographic characteristics of the elderly and mean of obesity knowledge and health behaviors related weight loss before and after the intervention. This is consistent with Seward, (2014) ${ }^{(64)}$ who mentioned that sociodemographic characteristics affect the prevalence of obesity, as well as the ability to lose weight, and also stated that income and education are major variables that affect not only the knowledge, but also the ability to follow the guidelines for weight loss behaviors.

\section{Conclusion}

In conclusion, this study reflects a significant weight loss 12 week after completing the intervention (a combination of healthy hypo-caloric diet, exercises, and behavioral change) with improvement in physical function particularly in obese elderly women. Moreover, there was a significant improvement in obesity knowledge and heath related behaviors among obese older adults with differences in the study group in term of demographic characteristics. Older adults' perception about their weight and perceived obesity risks were improved significantly after the intervention. Finally, obesity awareness, healthy behaviors, body weight, and physical activity are interrelated variables.

\section{Recommendations}

- The study findings reinforce the relevance of strategies that improve the awareness of elders regarding obesity and its adverse effects through health education programs in the outpatient clinics.

- Obesity prevention efforts should be applied in primary care settings, where health care providers have longitudinal relationship with geriatric patients and can provide a brief, motivational interviewing to engage them in behavioral change to maintain their weight.

- Future researches with larger study samples over long periods are needed to further evaluate the effects of a lifestyle-based weight loss intervention in obese older adults. Additionally, longer-term trials are needed to determine whether the weight loss is maintained with or without continued intervention.

\section{Acknowledgement}

We would like to thank all health personnel in the geriatric outpatient clinic at specialized medical hospital, Mansoura University, Egypt as well as older adults for their participation to fulfill this study. 
Table (1): Obesity knowledge of the studied elders pre and post-intervention and its variation with demographic characteristics

\begin{tabular}{|c|c|c|c|c|c|c|}
\hline \multirow[t]{2}{*}{ Items } & Total & $\begin{array}{c}\text { Pre- } \\
\text { intervention }\end{array}$ & $\begin{array}{c}\text { Immediate } \\
\text { post- } \\
\text { intervention }\end{array}$ & $\begin{array}{l}\text { 12week post- } \\
\text { intervention }\end{array}$ & \multirow[t]{2}{*}{$\begin{array}{c}\text { Paired } \\
\text { sample t- } \\
\text { test }\left(p^{1}\right)\end{array}$} & \multirow[t]{2}{*}{$\begin{array}{c}\text { Paired } \\
\text { sample } t- \\
\text { test }\left(p^{2}\right)\end{array}$} \\
\hline & $\mathbf{N}(\%)$ & Mean \pm SD & Mean \pm SD & Mean \pm SD & & \\
\hline Overall & 66 & $35.37 \pm 8.32$ & $61.00 \pm 9.57$ & $58.51 \pm 9.16$ & $61.5, \mathrm{p} \leq .001$ & $55.3, \mathrm{p} \leq .001$ \\
\hline \multirow{4}{*}{$\begin{aligned} \text { Age (years): } & 60- \\
& 65- \\
& 70+ \\
& \text {-value }^{a}\end{aligned}$} & $32(48.5)$ & $39.56 \pm 7.47$ & $65.5 \pm 9.41$ & $62.62 \pm 8.75$ & $35.1, \mathrm{p} \leq .001$ & $33.5, \mathrm{p} \leq .001$ \\
\hline & $22(33.3)$ & $32.9 \pm 7.51$ & $58.81 \pm 7.18$ & $57.09 \pm 6.36$ & $40.1, \mathrm{p} \leq .001$ & $35.4, \mathrm{p} \leq .001$ \\
\hline & $12(18.2)$ & $30.37 \pm 7.13$ & $55.00 \pm 8.79$ & $52.25 \pm 9.49$ & $42.7, \mathrm{p} \leq .001$ & $32.3, \mathrm{p} \leq .001$ \\
\hline & & $9.96(.000)^{*}$ & $8.91(.000)^{*}$ & $8.88(.000)^{*}$ & & \\
\hline \multirow{2}{*}{$\begin{array}{l}\text { Sex: Male } \\
\text { Female } \\
\text { p-value }\end{array}$} & $14(21.2)$ & $33.31 \pm 6.68$ & $60.5 \pm 8.63$ & $58.62 \pm 8.26$ & $29.1, \mathrm{p} \leq .001$ & $29.1, \mathrm{p} \leq .001$ \\
\hline & $52(78.8)$ & $\begin{array}{l}35.98 \pm 8.7 \\
1.12(.263)\end{array}$ & $\begin{array}{l}61.14 \pm 9.9 \\
.236(.814)\end{array}$ & $\begin{array}{l}58.48 \pm 9.48 \\
.055(.957)\end{array}$ & $56.1, \mathrm{p} \leq .001$ & $50.6, \mathrm{p} \leq .001$ \\
\hline \multirow{4}{*}{$\begin{array}{l}\text { Social status: } \\
\text { Married } \\
\text { Other }{ }^{\#} \\
\text { p-value }\end{array}$} & & & & & & \\
\hline & $40(60.6)$ & $38.31 \pm 7.96$ & $64.18 \pm 9.22$ & $61.72 \pm 8.5$ & $41.8, \mathrm{p} \leq .001$ & $38.3, \mathrm{p} \leq .001$ \\
\hline & $26(39.4)$ & $30.38 \pm 6.39$ & $55.61 \pm 7.64$ & $53.07 \pm 7.63$ & $61.7, \mathrm{p} \leq .001$ & $50.8, \mathrm{p} \leq .001$ \\
\hline & & $4.32(.000)^{*}$ & $3.99(.000)^{*}$ & $4.26(.000)^{*}$ & & \\
\hline \multirow{5}{*}{$\begin{array}{l}\text { Education: } \\
\text { Illiterate } \\
\text { Read \& write } \\
\text { Secondary } \\
\text { University } \\
\text { p-value }{ }^{a} \\
\end{array}$} & & & & & & \\
\hline & $26(39.4)$ & $30.53 \pm 5.31$ & $\begin{array}{l}56.15 \pm 7.31 \\
601+468\end{array}$ & $\begin{array}{l}54.31 \pm 7.51 \\
5755+522\end{array}$ & $\begin{array}{c}44.6 \leq .001 \\
253 \mathrm{n}<001\end{array}$ & $\begin{array}{l}39.7, \mathrm{p} \leq .001 \\
22.4 \mathrm{n}<001\end{array}$ \\
\hline & 22(33.3) & $\begin{array}{l}3.58 \\
7.94\end{array}$ & $\begin{array}{c}60.1 \pm 4.68 \\
70.33 \pm 7.57\end{array}$ & $\begin{array}{l}5 / .55 \pm 5.22 \\
67.16+6.93\end{array}$ & $\begin{array}{l}25.3, p \leq .001 \\
51.7, p<.001\end{array}$ & $\begin{array}{l}22.4, p \leq .001 \\
446 n<001\end{array}$ \\
\hline & $\begin{array}{c}12(10.2) \\
6(91)\end{array}$ & $\begin{array}{l}45.03 \pm 1.94 \\
4800+5.58\end{array}$ & $75.33+1.86$ & $7166+136$ & $162 \mathrm{n}<001$ & $131 \mathrm{n}<001$ \\
\hline & & $19.48(.000)^{*}$ & $17.96(.000)^{*}$ & $15.46(.000)^{*}$ & & \\
\hline \multirow{4}{*}{$\begin{array}{l}\text { Residence: } \\
\text { Rural } \\
\text { urban } \\
p \text {-value }\end{array}$} & & & & & & \\
\hline & $50(75.8)$ & $33.57 \pm 7.32$ & $58.4 \pm 8.52$ & $56.07 \pm 8.38$ & $54.2, \mathrm{p} \leq .001$ & $47.5, \mathrm{p} \leq .001$ \\
\hline & $16(24.2)$ & $40.55 \pm 9.04$ & $68.5 \pm 8.59$ & $65.55 \pm 7.67$ & $39.7, \mathrm{p} \leq .001$ & $33.9, \mathrm{p} \leq .001$ \\
\hline & & $3.27(.007) *$ & $4.32(.000) *$ & $4.22(.000)^{*}$ & & \\
\hline \multirow{3}{*}{$\begin{array}{l}\text { Living condition: } \\
\text { Alone } \\
\text { With family } \\
p \text {-value }{ }^{b} \\
\end{array}$} & & & & & & \\
\hline & 11(16.7) & $\begin{array}{l}33.00 \pm 7.82 \\
35.81+830\end{array}$ & $58.72 \pm 9.78$ & $\begin{array}{c}55.81 \pm 10.85 \\
5001+882\end{array}$ & $30.5, \mathrm{p} \leq .001$ & $21.3, \mathrm{p} \leq .001$ \\
\hline & $55(83.3)$ & $\begin{array}{c}35.81 \pm 8.39 \\
1.03(.307)\end{array}$ & $\begin{array}{c}61.42 \pm 9.55 \\
.85(.395)\end{array}$ & $\begin{array}{c}59.01 \pm 8.82 \\
1.06(.291)\end{array}$ & & \\
\hline \multirow{3}{*}{$\begin{array}{l}\text { Income: } \\
\text { Adequate } \\
\text { Inadequate } \\
p \text {-value }\end{array}$} & & & & & & \\
\hline & $19(28.8)$ & $36.56 \pm 8.56$ & $63.06 \pm 9.82$ & $60.06 \pm 9.56$ & $39.1, \mathrm{p} \leq .001$ & $34.4, \mathrm{p} \leq .001$ \\
\hline & $47(71.2)$ & $\begin{array}{r}34.84 \pm 6.3 \\
078(331)\end{array}$ & $\begin{array}{c}59.57 \pm 7.97 \\
179(078)\end{array}$ & $\begin{array}{l}57.52 \pm 7.73 \\
158(119)\end{array}$ & $47.3, \mathrm{p} \leq .001$ & $44.6, \mathrm{p} \leq .001$ \\
\hline \multirow{4}{*}{$\begin{array}{l}\text { Chronic diseases: } \\
\text { Yes } \\
\text { No } \\
p_{\text {-value }}{ }^{b}\end{array}$} & & & & & & \\
\hline & $59(89.4)$ & $35.75 \pm 8.31$ & $57.00 \pm 10.84$ & $52.33 \pm 12.9$ & $58.6, \mathrm{p} \leq .001$ & $51.2, \mathrm{p} \leq .001$ \\
\hline & $7(10.6)$ & $32.00 \pm 10.84$ & $60.58 \pm 9.32$ & $58.16 \pm 8.69$ & $26.8, \mathrm{p} \leq .001$ & $39.5, \mathrm{p} \leq .001$ \\
\hline & & $.533($. & $.691(.501)$ & & & \\
\hline \multirow{5}{*}{$\begin{array}{l}\mathrm{N} \text { of symptoms: } \\
\text { One } \\
\text { Two } \\
\text { Three }+ \\
p_{\text {-value }}{ }^{a}\end{array}$} & & & & & & \\
\hline & $12(18.2)$ & $30.50 \pm 7.32$ & $55.00 \pm 9.81$ & $52.66 \pm 9.31$ & $31.6, \mathrm{p} \leq .001$ & $36.1, \mathrm{p} \leq .001$ \\
\hline & $20(30.3)$ & $30.80 \pm 3.6$ & $55.30 \pm 4.54$ & $52.90 \pm 5.17$ & $24.1, \mathrm{p} \leq .001$ & $20.8, \mathrm{p} \leq .001$ \\
\hline & $34(51.5)$ & $39.31 \pm 8.45$ & $65.89 \pm 8.81$ & $63.31 \pm 8.06$ & $58.5, \mathrm{p} \leq .001$ & $51.2, \mathrm{p} \leq .001$ \\
\hline & & $12.44(.000)^{*}$ & $15.42(.000)^{*}$ & $000)^{*}$ & & \\
\hline \multirow{2}{*}{$\begin{array}{l}\text { Weight loss } \\
\text { efforts: } \\
\text { Yes }\end{array}$} & & & & & & \\
\hline & 13(19.7) & $43.30 \pm 8.67$ & $67.46 \pm 11.18$ & $64.53 \pm 10.43$ & $20.4, p \leq .001$ & $18.5, \mathrm{p} \leq .001$ \\
\hline \multirow{2}{*}{$\begin{array}{l}\text { No } \\
p \text {-value }\end{array}$} & $53(80.3)$ & $33.56 \pm 7.15$ & $59.52 \pm 8.61$ & $57.14 \pm 8.34$ & $60.7, \mathrm{p} \leq .001$ & $55.2, \mathrm{p} \leq .001$ \\
\hline & & $4.25(.002)^{*}$ & $2.83(.029) *$ & $2.75(.030)^{*}$ & & \\
\hline
\end{tabular}

\# widow (21) and divorced (5) ${ }^{a}$ One Way ANOVA ${ }^{b}$ Independent sample t-test

Paired-sample t-test $(p)^{l}$ : comparing pre and immediate post-intervention.

Paired-sample t-test $(p)^{2}$ : comparing pre and 12 week post-intervention.

* Significant at $p \leq 0.05$ 
Table (2): Health behaviors related to weight loss of the studied elders pre and postintervention and its variation with demographic characteristics

\begin{tabular}{|c|c|c|c|c|}
\hline \multirow[t]{2}{*}{ Items } & Total & $\begin{array}{c}\text { Pre- } \\
\text { intervention }\end{array}$ & $\begin{array}{l}\text { 12week post- } \\
\text { intervention }\end{array}$ & \multirow[t]{2}{*}{$\begin{array}{c}\text { Paired sample } \\
\text { t-test }(p)\end{array}$} \\
\hline & $\mathbf{N}(\%)$ & Mean \pm SD & Mean \pm SD & \\
\hline Overall & 66 & $10.64 \pm 1.35$ & $12.71 \pm 1.09$ & $31.92, \mathrm{p} \leq .001$ \\
\hline $\begin{array}{ll}\text { Age (years): } & 60- \\
& 65- \\
& 70+ \\
p^{p-v_{\text {value }}{ }^{a}} \\
\end{array}$ & $\begin{array}{l}32(48.5) \\
22(33.3) \\
12(18.2)\end{array}$ & $\begin{array}{c}11.25 \pm 1.22 \\
10.70 \pm 1.20 \\
9.35 \pm 0.872 \\
14.53(.000)^{*} \\
\end{array}$ & $\begin{array}{c}13.33 \pm 0.823 \\
12.73 \pm 0.840 \\
11.42 \pm 0.706 \\
29.97(.000)^{*}\end{array}$ & $\begin{array}{l}20.18, \mathrm{p} \leq .001 \\
15.98, \mathrm{p} \leq .001 \\
22.01, \mathrm{p} \leq .001\end{array}$ \\
\hline $\begin{array}{l}\text { Sex: Male } \\
\text { Female } \\
p_{\text {-value }}^{b}\end{array}$ & $\begin{array}{l}14(21.2) \\
52(78.8)\end{array}$ & $\begin{array}{c}9.90 \pm 1.24 \\
10.86 \pm 1.31 \\
2.57(.012)^{*}\end{array}$ & $\begin{array}{c}12.05 \pm 1.04 \\
12.90 \pm 1.03 \\
2.87(.005)^{*} \\
\end{array}$ & $\begin{array}{l}20.58, \mathrm{p} \leq .001 \\
26.12, \mathrm{p} \leq .001\end{array}$ \\
\hline $\begin{array}{l}\text { Social status: } \\
\text { Married } \\
\text { Other } \\
\text { p-value }^{b}\end{array}$ & $\begin{array}{l}40(60.6) \\
26(39.4)\end{array}$ & $\begin{array}{c}10.90 \pm 1.48 \\
10.19 \pm 0.982 \\
2.17(.033)^{*}\end{array}$ & $\begin{array}{c}12.92 \pm 1.11 \\
12.35 \pm 0.977 \\
2.14(.035)^{*}\end{array}$ & $\begin{array}{l}22.62, \mathrm{p} \leq .001 \\
24.79, \mathrm{p} \leq .001\end{array}$ \\
\hline $\begin{array}{l}\text { Education: } \\
\text { Illiterate } \\
\text { Read \& write } \\
\text { Secondary } \\
\text { University } \\
p_{\text {-value }}^{a}\end{array}$ & $\begin{array}{c}26(39.4) \\
22(33.3) \\
12(18.2) \\
6(9.1)\end{array}$ & $\begin{array}{c}9.32 \pm .64 \\
11.21 \pm .75 \\
11.49 \pm .81 \\
13.23 \pm .71 \\
31.64(.000)^{*}\end{array}$ & $\begin{array}{c}11.62 \pm .61 \\
13.05 \pm .38 \\
13.58 \pm .27 \\
14.75 \pm .26 \\
39.21(.000)^{*}\end{array}$ & $\begin{array}{c}28.31, \mathrm{p} \leq .001 \\
33.34, \mathrm{p} \leq .001 \\
9.89, \mathrm{p} \leq .001 \\
4.32, \mathrm{p} \leq .001\end{array}$ \\
\hline $\begin{array}{l}\text { Residence: } \\
\text { Rural } \\
\text { urban } \\
\text { p-value }^{b}\end{array}$ & $\begin{array}{l}50(75.8) \\
16(24.2)\end{array}$ & $\begin{array}{l}10.48 \pm 1.11 \\
11.10 \pm 1.85 \\
1.67(.098) \\
\end{array}$ & $\begin{array}{l}12.59 \pm 1.06 \\
13.04 \pm 1.28 \\
1.50(.137) \\
\end{array}$ & $\begin{array}{l}34.78, \mathrm{p} \leq .001 \\
10.68, \mathrm{p} \leq .001\end{array}$ \\
\hline $\begin{array}{l}\text { Living condition: } \\
\text { Alone } \\
\text { With family } \\
p_{\text {-value }}^{b}\end{array}$ & $\begin{array}{l}11(16.7) \\
55(83.3)\end{array}$ & $\begin{array}{l}9.81 \pm 0.872 \\
10.79 \pm 1.37 \\
2.27(.026)^{*}\end{array}$ & $\begin{array}{c}11.94 \pm 0.63 \\
12.85 \pm 1.102 \\
2.63(.010)^{*}\end{array}$ & $\begin{array}{l}16.84, \mathrm{p} \leq .001 \\
28.01, \mathrm{p} \leq .001\end{array}$ \\
\hline $\begin{array}{l}\text { Income: } \\
\text { Adequate } \\
\text { Inadequate } \\
\text { p-value }^{b} \\
\end{array}$ & $\begin{array}{l}19(28.8) \\
47(71.2)\end{array}$ & $\begin{array}{c}11.39 \pm 1.38 \\
10.01 \pm 0.96 \\
4.89(.000)^{*}\end{array}$ & $\begin{array}{c}13.38 \pm 0.92 \\
12.14 \pm 0.88 \\
5.76(.000)^{*}\end{array}$ & $\begin{array}{l}16.03, \mathrm{p} \leq .001 \\
37.26, \mathrm{p} \leq .001\end{array}$ \\
\hline $\begin{array}{l}\text { Chronic diseases: } \\
\text { Yes } \\
\text { No } \\
\text { p-value }^{b}\end{array}$ & $\begin{array}{l}59(89.4) \\
7(10.6)\end{array}$ & $\begin{array}{c}10.16 \pm 1.056 \\
10.57 \pm 1.25 \\
2.29(.108) \\
\end{array}$ & $\begin{array}{l}12.32 \pm 1.16 \\
12.56 \pm 1.11 \\
1.96(.148)\end{array}$ & $\begin{array}{c}31.19, \mathrm{p} \leq .001 \\
7.06, \mathrm{p} \leq .001\end{array}$ \\
\hline $\begin{array}{l}\text { N of symptoms: } \\
\text { One } \\
\text { Two } \\
\text { Three }+ \\
p_{\text {-value }}{ }^{a}\end{array}$ & $\begin{array}{l}12(18.2) \\
20(30.3) \\
34(51.5)\end{array}$ & $\begin{array}{c}10.34 \pm 1.28 \\
10.14 \pm 0.883 \\
11.00 \pm 1.49 \\
3.22(.046)^{*}\end{array}$ & $\begin{array}{l}12.15 \pm 0.98 \\
12.45 \pm 0.74 \\
13.02 \pm 1.18 \\
3.94(.024)^{*}\end{array}$ & $\begin{array}{l}17.52, \mathrm{p} \leq .001 \\
32.26, \mathrm{p} \leq .001 \\
19.66, \mathrm{p} \leq .001\end{array}$ \\
\hline $\begin{array}{l}\text { Weight loss efforts: } \\
\text { Yes } \\
\text { No } \\
p_{\text {-value }}{ }^{b}\end{array}$ & $\begin{array}{l}13(19.7) \\
53(80.3)\end{array}$ & $\begin{array}{l}11.82 \pm 1.60 \\
10.37 \pm 1.14 \\
3.80(.008)^{*}\end{array}$ & $\begin{array}{c}13.50 \pm 1.13 \\
12.53 \pm 1.007 \\
3.06(.012)^{*}\end{array}$ & $\begin{array}{c}9.31, \mathrm{p} \leq .001 \\
34.11, \mathrm{p} \leq .001\end{array}$ \\
\hline
\end{tabular}


Table (3): Comparison between outcome measures of the studied elders pre and postintervention and its variation by gender

\begin{tabular}{|c|c|c|c|c|}
\hline \multirow[t]{2}{*}{ Items } & \multirow[t]{2}{*}{ Gender } & Pre-intervention & $\begin{array}{l}\text { 12week post- } \\
\text { intervention }\end{array}$ & \multirow[t]{2}{*}{ paired t-test } \\
\hline & & Mean \pm SD & Mean \pm SD & \\
\hline \multirow[t]{3}{*}{ Weight $(\mathrm{kg})$} & Over all & $107.36 \pm 4.76$ & $103.31 \pm 6.12$ & $10.173, p \leq 0.001$ \\
\hline & Male & $106.69 \pm 3.71$ & $105.81 \pm 3.74$ & \\
\hline & Female & $107.56 \pm 5.04$ & $101.87 \pm 6.62$ & \\
\hline \multicolumn{2}{|l|}{ t-test $(p)$} & $.637(0.526)$ & $2.117(0.038)^{*}$ & \\
\hline \multirow[t]{3}{*}{$\operatorname{BMI}\left(\mathrm{kg} / \mathrm{m}^{2}\right)$} & Over all & $39.05 \pm 3.19$ & $37.54 \pm 3.48$ & $7.682, p \leq 0.001$ \\
\hline & \begin{tabular}{|l|} 
Male \\
\end{tabular} & $38.87 \pm 2.95$ & $38.207 \pm 3.11$ & \\
\hline & Female & $39.106 \pm 3.28$ & $37.34 \pm 3.58$ & \\
\hline \multicolumn{2}{|l|}{ t-test $(\mathrm{p})$} & $.252(0.801)$ & $.863(0.391)$ & \\
\hline \multirow{3}{*}{$\begin{array}{l}\text { Waist } \\
\text { circumference } \\
(\mathrm{cm})\end{array}$} & Over all & $107.16 \pm 7.82$ & $104.64 \pm 7.72$ & $18.161, \mathrm{p} \leq 0.001$ \\
\hline & Male & $109.38 \pm 6.96$ & $106.69 \pm 7.18$ & \\
\hline & Female & $106.50 \pm 8.008$ & $104.09 \pm 7.83$ & \\
\hline \multicolumn{2}{|l|}{ t-test (p) } & $1.296(0.199)$ & $1.184(0.240)$ & \\
\hline \multirow[t]{3}{*}{ PASE } & Over all & $38.6543 \pm 14.74$ & $55.4800 \pm 18.96$ & $11.576, p \leq 0.001$ \\
\hline & Male & $33.43 \pm 7.01$ & $47.11 \pm 16.81$ & \\
\hline & Female & $40.21 \pm 16.07$ & $57.98 \pm 18.97$ & \\
\hline \multicolumn{2}{|l|}{ t-test $(p)$} & $1.631(0.108)$ & $2.085(0.041)^{*}$ & \\
\hline \multirow{3}{*}{$\begin{array}{l}\text { Systole blood } \\
\text { pressure (mmhg) }\end{array}$} & Over all & $156.43 \pm 12.701$ & $148.10 \pm 15.88$ & $6.614, p \leq 0.001$ \\
\hline & Male $(\mathrm{N}=11)$ & $156.94 \pm 13.45$ & $149.19 \pm 16.98$ & \\
\hline & Female $(\mathrm{N}=31)$ & $155.00 \pm 10.72$ & $145.00 \pm 12.44$ & \\
\hline \multicolumn{2}{|l|}{ t-test $(\mathrm{p})$} & $.430(0.670)$ & $.748(0.459)$ & \\
\hline \multirow{3}{*}{$\begin{array}{l}\text { Diastole blood } \\
\text { pressure (mmhg) }\end{array}$} & Over all & $99.04 \pm 8.207$ & $92.61 \pm 6.73$ & $6.855, p \leq 0.001$ \\
\hline & Male $(\mathrm{N}=11)$ & $99.67 \pm 8.05$ & $93.54 \pm 6.85$ & \\
\hline & Female $(\mathrm{N}=31)$ & $97.27 \pm 8.76$ & $90.00 \pm 5.91$ & \\
\hline \multicolumn{2}{|l|}{ t-test $(p)$} & $.832(0.411)$ & $1.524(0.135)$ & \\
\hline
\end{tabular}

* Significant at $p \leq 0.05$

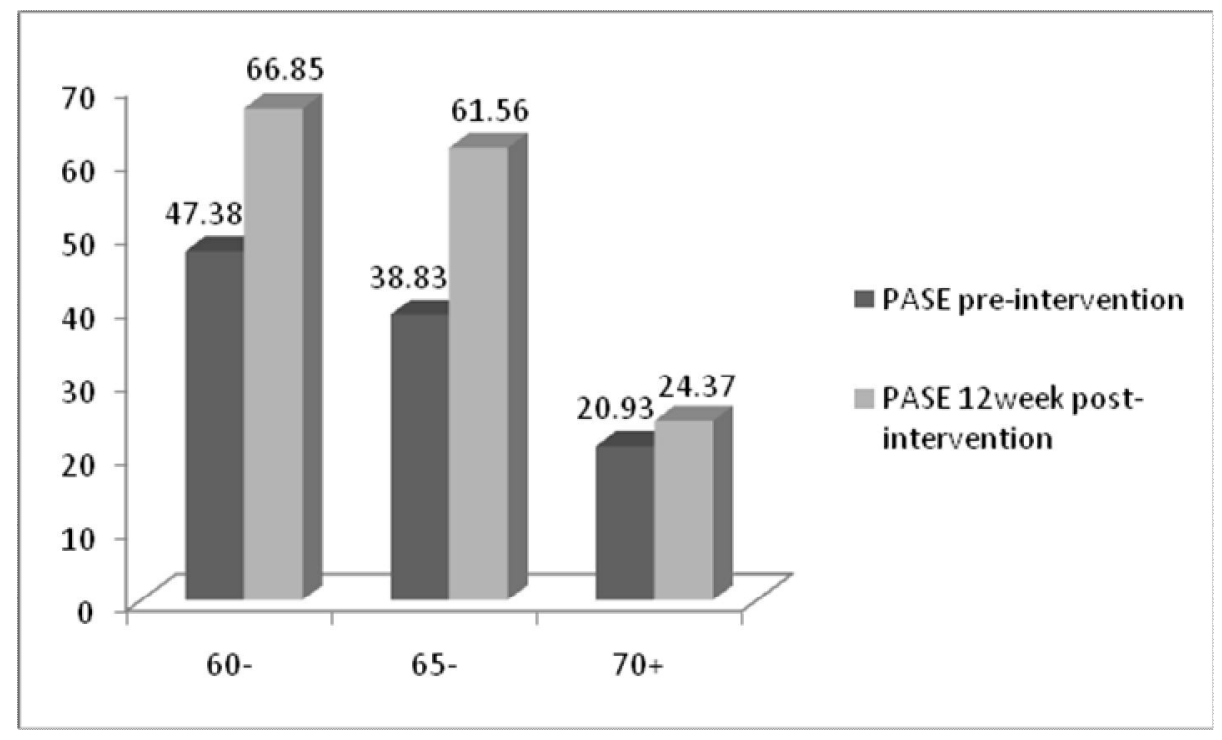

Figure (1): Physical activity of the studied elders (PASE) pre and 12 week post-intervention and its variation by age 
Table (4): Effect of nursing intervention related to weight loss on elders' self perception about their body weight and perceived obesity risks

\begin{tabular}{|c|c|c|c|}
\hline \multirow[t]{2}{*}{ Items } & Pre-intervention & $\begin{array}{l}12 \text { week post- } \\
\text { intervention }\end{array}$ & \multirow[t]{2}{*}{$\begin{array}{c}\text { Wilcoxon singed } \\
\text { ranks } \mathrm{Z} \text { test }\end{array}$} \\
\hline & $\mathbf{N}(\%)$ & $\mathbf{N}(\%)$ & \\
\hline $\begin{array}{l}\text { Self perception of body } \\
\text { weight: } \\
\text { About right } \\
\text { Over weight } \\
\text { Obese }\end{array}$ & $\begin{array}{c}11(16.7) \\
47(71.2) \\
8(12.1)\end{array}$ & $\begin{array}{c}- \\
9(13.6) \\
57(86.4)\end{array}$ & $\begin{array}{c}Z=7.758 \\
p \leq 0.001\end{array}$ \\
\hline $\begin{array}{l}\text { Risk for chronic diseases: } \\
\text { Never } \\
\text { Sometimes } \\
\text { Always }\end{array}$ & $\begin{array}{c}8(12.1) \\
36(54.6) \\
22(33.3)\end{array}$ & $\begin{array}{c}- \\
8(12.1) \\
58(87.9)\end{array}$ & $\begin{array}{c}\mathrm{Z}=6.687 \\
\mathrm{p} \leq 0.001\end{array}$ \\
\hline $\begin{array}{l}\text { Risk compared to other } \\
\text { elders: } \\
\text { More than other } \\
\text { No difference } \\
\text { Less than other }\end{array}$ & $\begin{array}{c}38(57.5) \\
24(36.4) \\
4(6.1)\end{array}$ & $\begin{array}{c}64(96.9) \\
2(3.1) \\
- \\
\end{array}$ & $\begin{array}{c}Z=5.285 \\
p \leq 0.001\end{array}$ \\
\hline
\end{tabular}

* Significant at $p \leq 0.05$

Table (5): Relation between studied elders' perceived obesity risks and the study variables

\begin{tabular}{||l|c|c|c||}
\hline \multirow{2}{*}{ Items } & $\begin{array}{c}\text { Total knowledge } \\
\text { score }\end{array}$ & $\begin{array}{c}\text { Total heath } \\
\text { behaviors score }\end{array}$ & BMI \\
\cline { 2 - 4 } & Mean \pm SD & Mean \pm SD & Mean \pm SD \\
\hline Risk for chronic diseases: & & & \\
Sometimes & $50.00 \pm 1.51$ & $12.03 \pm 1.16$ & $38.15 \pm 1.27$ \\
Always & $59.61 \pm 9.16$ & $12.88 \pm 1.06$ & $37.46 \pm 3.67$ \\
\hline t- test (p) & $2.945(0.004)^{*}$ & $2.207(0.013) *$ & $0.525(0.601)$ \\
\hline Risk compared to other & $58.85 \pm 9.05$ & $12.74 \pm 1.07$ & $37.43 \pm 3.46$ \\
elders: & $47.00 \pm 4.24$ & $11.56 \pm 1.506$ & $41.17 \pm 2.078$ \\
More than other & & & \\
No difference & $3.365(0.051)^{*}$ & $2.312(0.033)^{*}$ & $2.268(0.137)$ \\
\hline t- test (p) & \multicolumn{3}{|l}{} \\
\hline
\end{tabular}

* Significant at $p \leq 0.05$

Table (6): Correlation between the study variables

\begin{tabular}{|c|c|c|c|c|c|c|c|c|}
\hline \multirow[t]{3}{*}{ Items } & \multicolumn{8}{|c|}{ Study variables } \\
\hline & \multicolumn{2}{|c|}{$\begin{array}{c}\text { Total knowledge } \\
\text { score }\end{array}$} & \multicolumn{2}{|c|}{$\begin{array}{c}\text { Total heath } \\
\text { behaviors score }\end{array}$} & \multicolumn{2}{|c|}{ BMI } & \multicolumn{2}{|c|}{ PASE } \\
\hline & $\mathbf{r}$ & $\mathbf{p}$ & $\mathbf{r}$ & $\mathbf{p}$ & $\mathbf{r}$ & $\mathbf{p}$ & $\mathbf{r}$ & $\mathbf{p}$ \\
\hline $\begin{array}{l}\text { Total knowledge } \\
\text { score }\end{array}$ & 1.000 & --- & .550 & $0.000^{*}$ & -.631 & $0.000 *$ & .389 & $0.001 *$ \\
\hline \begin{tabular}{|l|} 
Total heath \\
behaviors score
\end{tabular} & .550 & $0.000^{*}$ & 1.000 & ----- & -.611 & $0.000 *$ & .637 & $0.000 *$ \\
\hline BMI & -.631 & $0.000 *$ & -.611 & $0.000 *$ & 1.000 & $\begin{array}{ll}--- \\
\end{array}$ & -.508 & $0.000 *$ \\
\hline PASE & .389 & $0.001 *$ & .637 & $0.000 *$ & -.508 & $0.000^{*}$ & 1.000 & ---- \\
\hline
\end{tabular}

* Significant at $p \leq 0.05$ 


\section{References}

1. Batsis $\mathrm{JA}$ and Zagaria $\mathrm{AB}$. Addressing obesity in aging patients. Med Clin North Am 2018; 102(1): 65-85.

2. Hurby A and Hu FB. The epidemiology of obesity: A big picture. PMC 2016; 33(7): 673-89.

3. Han TS, Tajar A, Lean MEJ. Obesity and weight management in the elderly. $\mathrm{Br}$ Med Bull 2011; 97:169-96.

4. World Health Organization 2018, Obesity and overweight: What are obesity and overweight? Available at: https://www.who.int

5. Kioh SH, Mat S, Myint PK, Tan MP. Could obesity be linked to falls in older adults?. Biomedical journal of scientific \& technical research 2019; 13 (1): $9716-$ 19.

6. Mendis S, Davis S, Norrving B. Organizational update: the world health organization global status report on noncommunicable diseases 2014; one more landmark step in the combat against stroke and vascular disease. Stroke 2015; 46(5): 121-22.

7. World Health Organization 2018, Obesity and overweight: Key facts. Available at: https://www.who.int

8. Flegal KM, Kruszon-Moran D, Carroll MD, Fryar CD, Ogden CL. Trends in obesity among adults in the United States, 2005 to 2014. JAMA 2016; 315(21): 2284-91.

9. Shebl AM, Hatata EZ, Boughdady AM, El-sayed SM. Prevalence and risk factors of obesity among elderly attending geriatric outpatient clinics in Mansoura city. Journal of Education and Practice 2015; 6(30): 136-47.

10. Jackson AS, Janssen I, Sui X, Church TS, Blair SN. Longitudinal changes in body composition associated with healthy ageing: men, aged 20-96 years. Br J Nutr 2012; 107(7): 1085-91.

11. Amarya S, Singh $\mathrm{K}$, Sabharwal $\mathrm{M}$. Ageing process and physiological changes. Open access books in web of science 2018; 2-24. http://dx.doi.org/10.5772/intechopen.762 49.

12. Faghri P, Stratton K, Momeni K. Sedentary Lifestyle, Obesity, and Aging: Implication for Prevention. Journal of nutritional disorders \& therapy 2015; 5(1):1-2.

13. Amarya S, Singh K, PhD, Sabharwal M. Health consequences of obesity in the elderly. Journal of Clinical Gerontology \& Geriatrics 2014; 5: 63-67.

14. Mathus Vliegen E. Obesity Management Task Force (OMTF) of the European Association for the Study of Obesity (EASO), Prevalence, Pathophysiology, Health Consequences and Treatment Options of Obesity in the Elderly: A Guideline. Obesity Facts 2012; 5(3): 460- 83.

15. Segula D. Complications of obesity in adults: A short review of the literature. Med Journal 2014; 26(1): 20-24.

16. Porter Starr KN, McDonald SR, Bales $\mathrm{CW}$. Obesity and physical frailty in older adults: a scoping review of lifestyle intervention trials. J. Am. Med. Dir. Assoc 2014; 15(4): 240-50.

17. Bell JA, Sabia S, Kivimaki M. Healthy obesity and risk of accelerated functional decline and disability. International Journal of obesity 2017; 41: 866-72.

18. Vincent HK, Vincent KR, Lamb KM. Obesity and mobility disability in the older adult. Obes Rev 2010; 11(8): 56879.

19. Ryan DH, Yockey SR. Weight loss and improvement in comorbidity: Differences at 5\%, 10\%, 15\%, and over. Currnt obesity reports 2017; 6 (2): 187-94.

20. Newman AB, Lee JS, Visser M, Goodpaster BH, Kritchevsky SB, Tylavsky FA, Nevitt M, Harris TB. Weight change and the conservation of lean mass in old age: Health, aging and body composition study. Am J Clin Nutr 2005; 82: 872-78. 
21. Villareal DT, Chode S, Parimi N, Sinacore DR, Hilton T, Villareal R, Napoli N, Qualls C, Shah K. Weight loss, exercise, or both and physical function in obese older adults. New England Journal of Med. 2011; 364: 1218-29.

22. Yumuk A, Tsigos C, Fried M, Schindler K, Busetto L, Micic D, Toplak H. Obesity Facts, European Guidelines for Obesity Management in Adults. The European journal of obesity 2015; 8: 402-24.

23. Rafii M, Chapman K, Owens J, Elango R, Campbell WW, Ball RO, Pencharz PB, Courtney-Martin G. Dietary protein requirement of female adults $>65$ years determined by the indicator amino acid oxidation technique is higher than current recommendations. J Nutr 2015; 145(1): 18-24.

24. American College of Sports Medicine, Chodzko-Zajko WJ, Proctor DN, Fiatarone Singh MA, Minson CT, Nigg CR, Salem GJ, Skinner JS. American College of Sports Medicine position stand. Exercise and physical activity for older adults. Med Sci Sports Exerc. 2009; 41: 1510-30.

25. Gill LE, Bartels SJ, Batsis JA. Weight management in older adults. Curr Obes Rep 2015; 4 (3): 379-88.

26. Wills T, Callen BL, Fehin P. Body mass index knowledge of older adults and motivation to change. British Journal of Community Nursing 2011; 16 (3): 11015.

27. Sajoux I, Bellon A, Josep V. Challenges in Treatment of Obesity in the Elderly. Endocrinol Metab Int Journal 2017; 5(5): $1-7$.

28. Mousa AMB, Soliman SM, Hawas SEA, Hatata EA. Effect of self care practice on lifestyle of elderly people with osteoarthritis knee. Published doctoral thesis. Faculty of Nursing. Mansoura University 2012.

29. Washburn RA, Smith KW, Jette AM, Janney CA. The physical Activity Scale for the Elderly (PASE): Development and evaluation. J Clin Epidemiol 1993; 46(2): 153-162.

30. Cruz JS. Applying New Obesity Guidelines. Today's Geriatric Medicine 2013; 7(2): 6 .

31. Clinical guidelines for weight management in New Zealand adults. Wellington: Minstry of Health 2017. Available at: https://heath.govt.nz.

32. Coker RH AND Wolfe RR. Weight loss strategies in the elderly: A clinical Conundrum. Obesity journal 2018; 26(1): 22-28.

33. Ard JD, Gower B, Hunter G, Ritchie CS, Roth DL, Goss A, Wingo BC, Bodner EV, Brown CJ, Bryan D, Buys DR, Hass MC, Keita AD, Flagg LA, Williams CP, Locher JL. Effects of Calorie Restriction in Obese Older Adults: The CROSSROADS Randomized Controlled Trial. J Gerontol A Biol Sci Med Sci 2018; 73(1):73-80.

34. Levy BR, Slade MD. Positive views of aging reduce risk of developing later-life obesity. Preventive Medicine Reports 2019; 13:196-98.

35. Bolina AF, Pegorari MS, Tavares DMDS. Obesity awareness among elders living in rural area: a household survey. Rev Bras Cineantropom Hum 2017; 19(5): 565-74.

36. Sabariah AH, Norhafizah AM. Prevalence of Overweight and Obesity in Elderly people from $\mathrm{Kg}$ Baru Sepang, Selangor, Malaysia. International Journal of Scientific and Research Publications 2017; 7(3): 421-29.

37. Fatmah F. Training Effect on Improving Cadres' Knowledge and Skills of Obesity and Hypertension in Older People. Makara Seri Kesehatan 2013; 17(2): 4954.

38. Nanda S, Mohabbat AB, Nagaraju D, Varayil JE, Ratrout B, Abu-Lebdeh HS, Majka AJ. Improving Awareness of Patients with Obesity and its Healthcare Implications. Quality in Primary Care 2015; 23(4): 201-204. 
39. Matson TE, Renz1 AD, Takemoto ML, McClure JB, Rosenberg DE. Acceptability of a sitting reduction intervention for older adults with obesity. BMC Public Health 2018; 18(706):1-12.

40. Newman A. Obesity in Older Adults. OJIN: The Online Journal of Issues in Nursing 2009; 14 (1): 1-8.

41. Villareal DT, Miller BV, Banks M, Fontana L, Sinacore DR, Klein S. Effect of lifestyle intervention on metabolic coronary heart disease risk factors in obese older adults. Am J Clin Nutr 2006; 84: 1317-23.

42. Nocera J, Buford TW, Manini TM, Naugle K, Leeuwenburgh C, Pahor M, Perri MG, Anton SD. The Impact of Behavioral Intervention on Obesity Mediated Declines in Mobility Function: Implications for Longevity. Journal of aging research 2011. doi:10.4061/2011/392510.

43. de Roon M, Gemert WA, Peeters PH, Schuit AJ, Monninkhof EM. Long-term effects of a weight loss intervention with or without exercise component in postmenopausal women: A randomized trial. Preventive medicine reports 2017; 5: 118-23.

44. Anton SD, Manini TM, Milsom VA, Dubyak P, Cesari M, Cheng J, Dniels MJ, Marsiske M, Pahor M, Leeuwenburgh C, Perri MG. Effects of a weight loss plus exercise program on physical function in overweight, older women: a randomized controlled trial. Clin. Interv. Aging 2011; 6: 141-49.

45. Jensen GL, Roy M, Buchanan AE, and Berg MB. Weight Loss Intervention for Obese Older Women: Improvements in Performance and Function. Obesity research 2004; 12(11): 1812-20.

46. Alrushud AS, Rushton AB, Bhogal G, Pressdee F, Greig CA. Effect of a combined programme of dietary restriction and physical activity on the physical function and body composition of obese middle-aged and older adults with knee OA (DRPA): protocol for a feasibility study. BMJ Open 2018; 8:110.
47. Betts AC and Froehlich-Grobe K. Accessible weight loss: Adapting a lifestyle intervention for adults with impaired mobility. Disability and Health Journal 2017; 10: 139-144.

48. Nicklas BJ, Chmelo E, Delbono O, Carr JJ, Lyles MF, Marsh AP. Effects of resistance training with and without caloric restriction on physical function and mobility in overweight and obese older adults: a randomized controlled trial. Am. J. Clin. Nutr 2015; 101: 99199.

49. Santanasto AJ, Glynn NW, Newman MA, Taylor CA, Brooks M, Goodpaster $\mathrm{PH}$ and Newman $\mathrm{AB}$. Impact of Weight Loss on Physical Function with Changes in Strength, Muscle Mass, and Muscle Fat Infiltration in Overweight to Moderately Obese Older Adults: A Randomized Clinical Trial. Journal of obesity 2011. doi:10.1155/2011/516576

50. Straight CR, Berg AC, Reed RA, Johnson M, Evans EM. Reduced body weight or increased muscle quality: Which is more important for improving physical function following exercise and weight loss in overweight and obese older women? Experimental Gerontology 2018; 108: 159-65.

51. Jackson SE, Holter L, Beeken RJ. Just because I'm old it doesn't mean I have to be fat: a qualitative study exploring older adults' views and experiences of weight management. BMJ Open 2019; 9: 1-11.

52. Takagi D, Nishida Y, Fujita D. Age associated changes in the level of physical activity in elderly adults. Journal of Physical Therapy Science 2015; 27(12): 3685-87.

53. Johannsen DL, Delany JP, Frisard MI, Welsch MA, Rowley CK, Fang X, Jazwinski SM, Ravussin E. Physical activity in aging: Comparison among young, aged, and nonagenarian individuals. Journal of Applied Physiology 2008; 105(2): 495-501.

54. Boo S. Body Mass Index and Weight Loss in Overweight and Obese Korean Women: The Mediating Role of Body 
Weight Perception Asian Nursing Research 2013; 7: 191-97.

55. Sanchez CM, Visser D. Self perception of body weight status in older Dutch adults. The journal of nutrition, health \& aging 2015; 19(6): 612-18.

56. A bd Elsalam RM and Elkholy SE.The relationship between Obesity and Health Status among Community dwelling Older Adults. Journal of Nursing and Health Science 2017; 6(6): 1-9.

57. Muhihi AJ, Njelekela MA, Mpembeni R, Mwiru RS, Mligiliche $\mathrm{N}$ and Mtabaji J. Obesity, Overweight, and Perceptions about Body Weight among Middle-Aged Adults in Dar es Salaam, Tanzania. International Scholarly Research Network, ISRN Obesity 2012. doi:10.5402/2012/368520

58. AL Khayyal H, El Geneidy M, El Shazly SA. Elders' Knowledge about Risk Factors of Coronary Heart Disease, Their Perceived Risk, and Adopted Preventive Behaviors. Journal of education and practice 2016; 7(10): 89-98.

59. Young H, Young C. Health Perception, Health Concern, and Health Promotion Behavior of the Elders. J Korean Gerontol Nurs 2013; 15(3): 277-85.
60. Hee JJ, Soon KJ. Health Literacy, Health Risk Perception and Health Behavior of Elders. J Korean Acad Community Health Nurs 2014; 25(1): 65-73.

61. Fenner DK. health perceptions and health behaviors in the elderly aged 65 years and older. Published master thesis of science in nursing. University of Michigan - Flint 2002.

62. Al-Wehedy A, Abd Elhameed SH, Abd Elhameed D. Effect of Lifestyle Intervention Program on Controlling Hypertension among Older Adults. Journal of education and practice 2014; 5(5): 61-71.

63. Mills C, Hayward J. An investigation into body mass index and lifestyle characteristics within an elderly population. Obes Res Open Journal 2016; 3(2): 18-23.

64. Seward H. Socioeconomic status and weight loss behaviors. Published master thesis-science in sociology-Virginia Commonwealth University 2014. 